\title{
Micronucleus frequency among Iraqi thyroid disorder patients
}

\author{
Abdul Hussein Moyet AlFaisal • \\ Intesar Jawad Kahdoom AL-Ramahi • \\ Ismail Abdul Redah Abdul-Hassan
}

Received: 13 April 2012 / Accepted: 12 December 2012 /Published online: 28 December 2012

(C) The Author(s) 2012. This article is published with open access at Springerlink.com

\begin{abstract}
Micronucleus (MN) assay has been extensively used in detection of DNA damage, instability in cancer, and genetic disorders. In the current study, $\mathrm{MN}$, binucleated cells, and nuclear division index (NDI) were investigated in Iraqi patients with thyroid disorders. The results indicated significantly $(p<0.05)$ increased binucleated cells with micronucleus (BNMN) frequencies in thyroid cancer group $(37.58 \pm 3.07)$ versus other thyroid disorder groups $(6.60 \pm$ $1.29,14.90 \pm 1.69,15.56 \pm 1.76)$. On the other hand, the frequency of micronucleus per 1,000 and the NDI were significantly $(p<0.05)$ decreased in hypothyroidism (MN $1.55 \pm 0.36$ ) (NDI $0.009 \pm 0.001)$ versus other thyroid disorder groups (MN: $6.05 \pm 0.97,6.09 \pm 0.53,5.34 \pm 0.56$ ) (NDI: $0.049 \pm 0.003,0.032 \pm 0.002,0.025 \pm 0.002)$, with no difference versus healthy group $(0.0 \pm 0.0)$. The number of BNMN and $\mathrm{MN}$ are parallel to the severity of thyroid disorders which were $6.60 \pm 1.29,14.90 \pm 1.69,15.56 \pm 1.76$, and $37.58 \pm 3.07$ for hypothyroidism, thyroid toxic goiter, thyroid nontoxic goiter, and thyroid cancer, respectively. The number of BNMN and $\mathrm{MN}$ are parallel to the severity of thyroid disorders which were $6.60 \pm 1.29,14.90 \pm 1.69,15.56 \pm 1.76$, and $37.58 \pm 3.07$ for hypothyroidism, thyroid toxic goiter, thyroid nontoxic goiter, and thyroid cancer, respectively. The results also indicate that there were no significant differences among age and sex groups as related with BNMN formation within each thyroid disorder groups and healthy control group.
\end{abstract}

A. H. M. AlFaisal $(\bowtie) \cdot$ I. A. R. Abdul-Hassan

Genetic Engineering and Biotechnology Institute, Baghdad, Iraq

e-mail: alfais2000@yahoo.com

I. J. K. AL-Ramahi

Al-Razi Centre for Medical Diagnostic kits Production,

Ministry of Industry, Baghdad, Iraq
Keywords Thyroid disorders $\cdot$ Micronucleus $\cdot$ NDI $\cdot$ BN

\section{Introduction}

Chromosomal damages measurement is one of important ways to evaluate the toxicity, carcinogenicity, and mutagenicity of drugs, chemicals, and rays (Cotterill et al. 2001; Ge et al. 2005; Gad and Saad 2008). Such damages were also detected to associate with some diseases and cancer (Fenech 2000; Neri et al. 2005; El-Zein et al. 2008, 2011). Most of these damages appeared as gene mutations and chromosomal rearrangements or appeared as free genetic particles near nucleus such as micronucleus or genetic balls distributed along cell cytoplasm such as double minutes (Gil et al. 2000; Herrmann 2003; Joseph et al. 2009). Many protocols were used to evaluate the genetic effects of these harmful factors; most of them are long, complicated, and costly assays. Micronucleus assay proofed to be the preferred method for assessing chromosome damage because they enable both chromosome loss and chromosome breakage to be measured reliably (Fenech 2000; 2002; Joseph et al. 2009). Micronucleus (MN) is arise during cell division when a whole lagging acentric chromosome or chromosome with nonfunctional centromere or damaged chromosomes (Leach and Cook 2004; AlFaisal 2007; AlFaisal et al. 2010). These oval or circular bodies do not integrate to the daughter nuclei and appeared as highly stained bodies beside nucleus membrane. The principle of the micronucleus assay is by adding of cytochalasin $\mathrm{B}$ to the cell cultures to block cytokinesis cell cultures which lead to the formation of micronuclei in bi- or multinucleated interphase cells (Fenech 2000). This assay has been extensively used in routine mutagen and carcinogen screening protocols to detect factors and agents that cause chromosomal damages and cytological toxicity as well to evaluate the genetical and 
cytological damages to lymphocytes of cancer patients before and after radiotherapy (Hooman et al. 2008). Recently, COMET assay was applied to detect DNA damages in thyroid patients before and after treatment (Ge et al. 2005).

The present study was performed to determine the genetic damages and DNA instability via MN assay associated with various types of thyroid disorders.

\section{Material and methods}

\section{Subjects}

Five study groups have been investigated. Apparently healthy control group consists of 25 healthy individuals of different ages. No obvious abnormalities were selected from blood bank donors for comparison. One hundred patients with thyroid disorders who attend the endocrinologist in Nuclear Medicine Hospital and Al Yarmok Nuclear Medicine Department in Baghdad, Iraq were selected. Clinical, ultrasonication, and serum thyroid hormones were used for diagnosis. Healthy controls and patients' ages ranged from 17 to 79 years. All patients were suffering from thyroid disorders such as toxic goiter, thyroid nontoxic goiter, thyroid hypothyroidism, and thyroid cancer in Baghdad during a period from July 2009 to October 2009.

\section{Blood samples}

Venous blood sample $(3 \mathrm{ml})$ was collected in heparinized tubes by trained nurses from each individual of both thyroid disorder and healthy control groups.

\section{Blood culture protocol}

Blood culture protocol was done according to Fenech (2000). A $0.5-\mathrm{ml}$ blood sample was added to culture tubes containing $4.5 \mathrm{ml}$ of RPMI 1640 media enriched with $20 \%$ fetal calf serum and $0.2 \mathrm{ml}$ of phytohemagglutinin $1 \%$ in each. Tubes were mixed gently by inverting a few minutes and incubated for $44 \mathrm{~h}$ at $37{ }^{\circ} \mathrm{C}$ in a slant position. Cytochalasin $\mathrm{B}$ was then added to each culture at a concentration of $3 \mu \mathrm{g} / \mathrm{ml}$ to block cell cytokinesis, and cultures were reincubated at $37{ }^{\circ} \mathrm{C}$ for further $28 \mathrm{~h}$. Cells were then harvested by centrifugation at 2,000 rpm for $10 \mathrm{~min}$. Supernatant was discarded by pipetting the media, leaving a little medium as possible over the cell pellet. Cell pellet was resuspended in the supernatant remains, and $10 \mathrm{ml}$ of warm hypotonic $(0.075 \mathrm{M} \mathrm{KCl})$ solution was added gently to each tube. Tubes were then mixed and incubated for $30 \mathrm{~min}$ in a water bath at $37^{\circ} \mathrm{C}$. The tubes were centrifuged at 2,000 rpm for $10 \mathrm{~min}$; the supernatant was discarded; and the pellet was resuspended in the supernatant remains, and
$5 \mathrm{ml}$ of fixative solution was added gently to each tube. Tubes were kept in refrigerator for about $30 \mathrm{~min}$. The tubes were centrifuged, and the supernatant was discarded. Fixation steps were repeated for three more times. After the final centrifugation, the cells were resuspended in a small volume of fixative solution (approximately 0.5$1 \mathrm{ml}$ ) depending on the size of cell bottom to give a slightly opaque suspension.

Slide preparation and estimation

Slides were prepared in order to examine the micronuclei formation and the nuclear division index. Before use, the slides were cleaned well with methanol then with distilled water. After that, the fixed lymphocyte cells were dropped from about $30-\mathrm{cm}$ height using a Pasteur pipette onto slides which were dried at $37{ }^{\circ} \mathrm{C}$ (Lamberti et al. 1983), stained with Giemsa stain, and examined by light microscope $(\times 40$ and $\times 100$ ). At least 1,000 binucleated cells per duplicate cell culture were scored to assess the frequency of cells with one, two, or more than two micronuclei. Additionally, the cells were classified as mononucleates, binucleates, or multinucleates (Kirsch-Volders et al. 1997). The frequency of binucleate and micronuclei were calculated as follow:

Binucleated cells with micronucleus (BNMN)

$$
/ 1,000 \text { binucleated cells }(1,000 \mathrm{BN})
$$

Number of MN/1, 000 binucleated cells $(1,000$ BN)

Nuclear division index

The proliferation index was estimated by measuring the nuclear division index according to Lamberti et al. (1983).

$$
\begin{aligned}
& \mathrm{NDI}=[1(\mathrm{M} 1 \%)+2(\mathrm{M} 2 \%)+3(\mathrm{M} 3 \%)+4(\mathrm{M} 4 \%)] / \mathrm{N} \\
& \mathrm{MN}=[1(\mathrm{MN} 1)+2(\mathrm{MN} 2)+3(\mathrm{MN} 3)+4(\mathrm{MN} 4) / \mathrm{N}]
\end{aligned}
$$

NDI Nuclear division index.

M, 1, 2, 3, $4 \quad$ Number of binucleated cells with micronucleus.

MN, 1, 2, 3, 4 Number of micronucleus in binucleated cells.

$N \quad$ Total number of cells.

\section{Results}

A total number of BNMN per 1,000 and MN per 1,000 were calculated for each patient group and compared with healthy (control) group (Fig. 1). 
Fig. 1 Binucleate (BN) cells with Micronucleus $(M N)$ in thyroid disorders patients $(\times 100)$

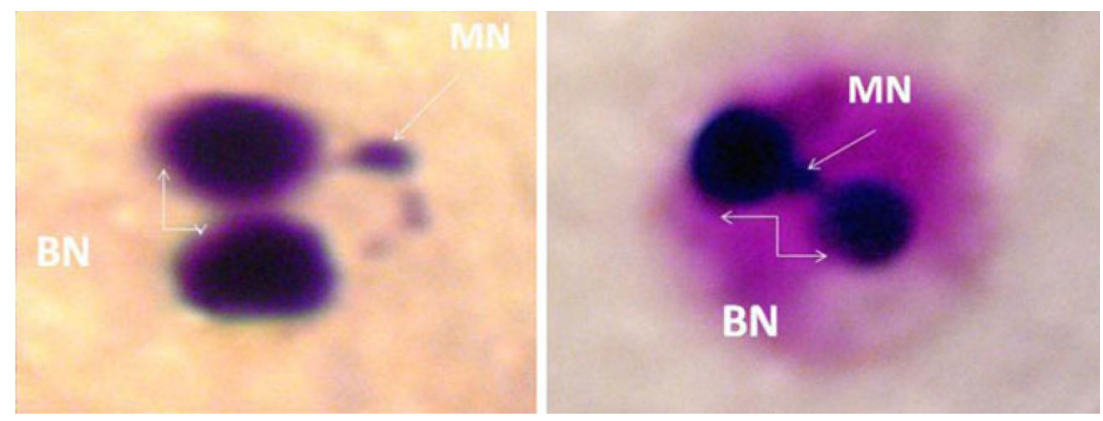

The numbers of micronuclei per 1,000, binucleated cell with micronuclei per 1,000 , and NDI in peripheral blood lymphocytes of Iraqi thyroid disorders compared with healthy control group are summarized in Table 1.

The results indicated significantly $(p<0.05)$ increased BNMN frequencies in thyroid cancer group $(37.58 \pm 3.07)$ versus hypothyroidism, thyroid toxic goiter, and thyroid nontoxic goiter groups $(6.60 \pm 1.29,14.90 \pm 1.69$, and $15.56 \pm$ 1.76 , respectively). Also, significant $(p<0.05)$ increase in other thyroid disorder groups versus healthy control $(0.0 \pm$ $0.0)$ were observed. While the frequency of micronucleus per 1,000 significantly $(p<0.05)$ decreased in hypothyroidism $(1.55 \pm 0.36)$ versus other thyroid disorder groups $(6.05 \pm 0.97$, $6.09 \pm 0.53,5.34 \pm 0.56$ ), with no difference in the frequency of micronucleus per 1,000 between hypothyroidism group and healthy group $(0.0 \pm 0.0)$. In addition, there were no significant differences in micronuclei per 1,000 among thyroid cancer, thyroid toxic goiter, and nontoxic goiter $(6.05 \pm 0.97,6.09 \pm$ 0.53 , and $5.34 \pm 0.56$ respectively).

The NDI frequencies were significantly decreased in hypothyroidism $(0.009 \pm 0.001)$ compared with thyroid cancer, thyroid toxic, and nontoxic goiter groups $(0.049 \pm 0.003$, $0.032 \pm 0.002$, and $0.025 \pm 0.002$, respectively). There is no significant difference in NDI frequencies among thyroid cancer, thyroid toxic, and thyroid nontoxic goiter $(0.049 \pm$ $0.003,0.032 \pm 0.002$, and $0.025 \pm 0.002$, respectively).

The number of BNMN and MN are parallel to the severity of thyroid disorders which were $6.60 \pm 1.29,14.90 \pm 1.69$, $15.56 \pm 1.76$, and $37.58 \pm 3.07$ for hypothyroidism, thyroid toxic goiter, thyroid nontoxic goiter, and thyroid cancer, respectively.

Tables 2 and 3 illustrated results of related micronuclei formation rates with age and sex groups. There were no significant differences among age and sex groups as related with BNMN formation within each thyroid disorder groups and healthy control group (Table 2).

\section{Discussion}

MN frequency is a biomarker of chromosomal damage, genome instability, and cancer risk that integrates acquired mutations and genetic susceptibility (Fenech 2000; Joseph et al. 2009). In addition, the NDI and the proportion of binucleated cells are biomarkers of mutagen response and immune function in lymphocytes as well as cytostatic effects of agents (Kocaman et al. 2008; Bonassi et al. 2011; El-Zein et al. 2011). In thyroid disorders, micronucleus assay was used as well to other cytogenetic assays such as chromosomal aberrations assay (Wilkens et al. 2000; Hooman et al. 2008), micronuclei assays associated with fluorescence in situ hybridization (FISH) ( Joseph et al. 2009), and COMET assay (Ge et al. 2005).

The current results indicated that significantly increased BNMN frequencies in thyroid cancer group versus other thyroid disorder groups which reflect a high proliferative rate, high level of genetic damage and cytotoxicity of cancer, and less rate but significant in other groups. The results

Table 1 Frequency of BNMN, MN, and NDI (mean \pm SE) among Iraqi thyroid disorders patients and apparently healthy control

\begin{tabular}{llrr}
\hline Groups & NDI & Micronucleus MN/1,000 & BNMN/1,000 \\
\hline Hypothyroidism & $0.009 \pm 0.001 \mathrm{~b}$ & $1.55 \pm 0.36 \mathrm{~b}$ & $6.60 \pm 1.29 \mathrm{c}$ \\
Thyroid Cancer & $0.049 \pm 0.003 \mathrm{a}$ & $6.05 \pm 0.97 \mathrm{a}$ & $37.58 \pm 3.07 \mathrm{a}$ \\
Thyroid Toxic goiter & $0.032 \pm 0.002 \mathrm{a}$ & $6.09 \pm 0.53 \mathrm{a}$ & $14.90 \pm 1.69 \mathrm{~b}$ \\
Thyroid Nontoxic goiter & $0.025 \pm 0.002 \mathrm{a}$ & $5.34 \pm 0.56 \mathrm{a}$ & $15.56 \pm 1.76 \mathrm{~b}$ \\
Healthy control & $0.000 \pm 0.000 \mathrm{c}$ & $0.0 \pm 0.0 \mathrm{~b}$ & $0.000 \pm 0.000 \mathrm{~d}$ \\
\hline
\end{tabular}

Significant differences at $(p<0.05)$. Different letters refer to significant differences among means

$B N M N$ Binucleate cells with micronucleus, $M N$ Micronucleus, $N D I$ Nuclear Division Index 
Table 2 Frequencies of BNMN, $\mathrm{MN}$, and NDI (mean $\pm \mathrm{SE}$ ) among Iraqi thyroid disorders patients according to age

\begin{tabular}{|c|c|c|c|c|}
\hline \multirow[t]{2}{*}{ Group $\backslash$ Parameter } & \multicolumn{4}{|l|}{ Age year } \\
\hline & $<30$ & $30-50$ & $>50$ & LSD (ns) \\
\hline \multicolumn{5}{|l|}{ Hypothyroidism } \\
\hline $\mathrm{BNMN} / 1,000$ & $1.00 \pm 0.18$ & $1.50 \pm 0.32$ & $2.16 \pm 0.83$ & 2.003 \\
\hline $\mathrm{MN} / 1,000$ & $7.00 \pm 2.86$ & $6.50 \pm 1.50$ & $6.33 \pm 2.95$ & 7.370 \\
\hline NDI & $0.009 \pm 0.002$ & $0.009 \pm 0.001$ & $0.01 \pm 0.004$ & 0.009 \\
\hline \multicolumn{5}{|l|}{ Thyroid cancer } \\
\hline BNMN/1,000 & $7.00 \pm 2.79$ & $5.72 \pm 1.20$ & $6.00 \pm 1.00$ & 7.160 \\
\hline $\mathrm{MN} / 1,000$ & $37.50 \pm 4.33$ & $39.27 \pm 4.14$ & $28.50 \pm 11.50$ & 20.541 \\
\hline NDI & $0.042 \pm 0.002$ & $0.051 \pm 0.004$ & $0.052 \pm 0.002$ & 0.022 \\
\hline \multicolumn{5}{|c|}{ Thyroid toxic goiter } \\
\hline $\mathrm{BNMN} / 1,000$ & $6.25 \pm 0.81$ & $6.68 \pm 0.82$ & $4.57 \pm 0.97$ & 2.738 \\
\hline $\mathrm{MN} / 1,000$ & $12.12 \pm 3.58$ & $14.31 \pm 1.76$ & $19.42 \pm 4.85$ & 9.032 \\
\hline NDI & $0.034 \pm 0.004$ & $0.0034 \pm 0.003$ & $0.026 \pm 0.004$ & 0.011 \\
\hline \multicolumn{5}{|c|}{ Thyroid nontoxic goiter } \\
\hline $\mathrm{BNMN} / 1,000$ & $3.50 \pm 1.50$ & $4.94 \pm 0.73$ & $6.15 \pm 0.95$ & 4.249 \\
\hline $\mathrm{MN} / 1,000$ & $19.50 \pm 13.50$ & $15.94 \pm 2.88$ & $14.46 \pm 1.64$ & 12.812 \\
\hline NDI & $0.026 \pm 0.016$ & $0.024 \pm 0.003$ & $0.026 \pm 0.003$ & 0.019 \\
\hline
\end{tabular}

Ns nonsignificant

possibility of chronic exposure to genotoxic agents such as radiations. Such genotoxicity was also detected as mutations in TPO and TG genes among Iraqi thyroid disorders patients (AlFaisal et al. 2012; Al-Ramahi et al. 2012). After Gulf war I in 1981, Gulf war II in 1991, and Gulf war III in 2003, the Iraqi environment radiation contamination was well documented (Al-Azzawi and Al-Saji 1999; IFAM 1995; AlAzzawi et al. 1999, 2002; Butrus et al. 2002), and the incidences of various types of cancer and genetic disorders due to this contamination were arisen (Al-Sadoon et al. 1998; Yaqoub et al. 1998a, b, 1999, 2002; Ali and Al-Ali 2002). This possibility is supported by the genotoxicity associated with radiations which were observed by several studies. Such studies have investigated the level of genome damage and micronucleus in thyroid cancer patients environmentally exposed to radiation after the Chernobyl fallout (Sbrana et al. 2006; Tronko et al. 2007; Cardis and Hatch 2011), after Fukushema in Japan (Medalia 2011), in patients affected by thyroid cancer who underwent radiotherapy (Livingston et al. 1993; Gutierrez et al. 1997, 1999; Dardano et al. 2007; Hooman et al. 2008), and in people affected by thyroid nodules following occupational exposure to ionizing radiation (Brooks et al. 2007; Scarpato et al. 2009).

The results of the current study also showed that no significant differences among age and sex groups as related with BNMN formation within each thyroid disorder groups and healthy control group. These results are correspondents to those by Scarpato et al. (2011) who reported that gender and age did not cause variation in the MN baseline level. Other literature regarding gender and $\mathrm{MN}$ showed that the 
frequencies of $\mathrm{MN}$ are greater in females than in males (Thierens et al. 2000; Joseph et al. 2009).

Open Access This article is distributed under the terms of the Creative Commons Attribution License which permits any use, distribution, and reproduction in any medium, provided the original author(s) and the source are credited.

\section{References}

Al-Azzawi S, Al-Saji M (1999) Effects of radioactive on surface and ground water in selected regions in southern Iraq. J Arabic Univ Assoc 6(1):35-45

Al-Azzawi S et al (1999) Environmental pollution resulting from the use of depleted Uranium weaponry against Iraq during 1991. J Arabic Univ Assoc Coll Eng Univ Baghdad 6(2):11-23

Al-Azzawi S, Maarouf B, Hussein S (2002) Environmental consequences resulted from the use of DU weapons on soil and air at selected areas in al-Basrah governorate. J Eng Univ Baghdad 7 (1): $1-20$

AlFaisal AHM (2007) Genotoxic effects among petrol station workers. J Fac Med Baghdad 49(3):326-330

AlFaisal AHM, Hussein MA, Abdul Kaleg A-R (2010) Estimation of DNA damages, cytotoxicity and antioxidant status of heavy metals and benzene among petrol workers in Baghdad-Iraq. IJPS 6(1):85-94

ALFaisal AHM, AL-Ramahi IJ, Abudl-Hassan IA, Hamdan AT, Barusrux S (2012) Detection of heterozygous c. $1708 \mathrm{C}>\mathrm{T}$ and c.1978C $>\mathrm{G}$ thyroid peroxidase (TPO) mutations in Iraqi patients with toxic and non toxic goiter. Comp Clin Path J 21(89):1-7

Ali A, Al-Ali J (2002) Chronic myeloid leukemia in Basrah after the Gulf War II, Proceedings of the conference on the effects of the use of DU weaponry on human and environment in Iraq, March 26-27, 2002 Baghdad Iraq

AL-Ramahi IJ, AL-Faisal AHM, Abudl-Reda I, Aouda N, AL-Atar R, Barusrux S (2012) Screening of g.IVS5 + $1 \mathrm{G}$ to a mutation of $T G$ gene and thyroid hormone level among Iraqi thyroid disorders. J Med Genet Genomics 4(1):1-5

Al-Sadoon I, Hassan J, Yaqoub A (1998) Incidence and pattern of congenital anomalies among birth in Basrah during the period 1990-1998. Proceeding of the conference on health and environmental consequences of DU used by U.S. and British forces in the 1991 Gulf War, Dec. 2-3, 1998, Baghdad, Iraq

Bonassi D, El-Zein R, Bolognesi C, Fenech M (2011) Micronuclei frequency in peripheral blood lymphocytes and cancer risk: evidence from human studies. Mutagenesis 26(1):93-100

Brooks AL, Hui TE, Couch LA (2007) Very large amounts of radiation are required to produce cancer. Dose-response 5:263-274

Butrus S, Wartan K, Butrus L (2002) Assessing radioactive contamination levels in Basrah governorate, Proceedings of the conference on the effects of the use of DU weaponry on human and environment in Iraq, March 26-27, 2002, Baghdad, Iraq, published in Arabic

Cardis E, Hatch M (2011) The Chernobyl accident - an epidemiological perspective. Clin Oncol 23(4):251-260

Cotterill SJ, Pearce MS, Parke L (2001) Thyroid cancer in children and young adults in the North of England. Is increasing incidence related to the Chernobyl accident? Eur J Cancer 37(8):1020-1026

Dardano A, Ballardin M, Ferdeghini M, Lazzeri E, Traino C, Caraccio N (2007) Anticlastogenic effect of Ginkgo biloba extract in Graves' disease patients receiving radioiodine therapy. J Clin Endocrinol Metab 92:4286-4289

El-Zein RA, Fenech F, Lopez MS, Spitz MR, Etzel CJ (2008) Cytokinesis-blocked micronucleus cytome assay biomarkers identify lung cancer cases amongst smokers. Cancer Epidemiol Biomarkers Prev 17:1111-1119

El-Zein R, Vral A, Etzel CJ (2011) Cytokinesis-blocked micronucleus assay and cancer risk assessment. Mutagenesis 26(1):101-106

Fenech M (2000) The in vitro micronucleus technique. Mutat Res 455:81-95

Fenech M (2002) Chromosomal biomarkers of genomic instability relevant to cancer. Drug Discov Today 7:1128-1137

Gad NS, Saad AS (2008) Effect of environmental pollution by phenol on some physiological parameters of Oreochromis niloticus. Glob Vet 2(6):312-319

Ge Y, Ning H, Wang S, Wang J (2005) DNA Damage in thyroid gland cells of rats exposed to long term intake of high fluoride and low iodine. Fluoride 38(4):318-323

Gil OM, Oliveira NG, Rodrigues AS, Laires A, Ferreira TC, Limbert E, Rueff J (2000) No evidence of increased chromosomal aberrations and micronuclei in lymphocytes from nonfamilial thyroid cancer patients prior to radiotherapy. Cancer Genet Cytogenet 123(1):55-60

Gutierrez S, Carbon E, Galore PA, Marcos R (1997) Micronuclei induction by 131I exposure study in hyperthyroidism patients. Fundam Mol Mech Mutagen 373(1):1-153

Gutierrez S, Carbonell E, Galore P, Creus A, Marcos R (1999) Cytogenetic damage after 131-iodine treatment for hyperthyroidism and thyroid cancer. A study using the micronucleus test. Dec Eur J Nucl Med 26(12):1589-1596

Herrmann M (2003) Standard and molecular cytogenetics of endocrine tumors. Am J Clin Pathol 119(sup1):17s-38s

Hooman A, Mogharrabi M, Solooki M, Mosaffa N, Tabeie F, Shafiee B, Neshandar IA (2008) Radioiodine therapy induced cytotoxicity in patients with differentiated thyroid carcinoma. Int $\mathrm{J}$ Endocrinol Metab 6(3):135-139

Iraq Foreign Affairs Ministry-IFAM (1995) "Radiation effects", an official paper submitted by the Iraqi delegation to the briefing meeting on nuclear liability during the 42 nd Session of the General Conference Vienna 1995

Joseph LJ, Bhartiya US, Raut YS, Kand P, Hawaldar RW, Nair N (2009) Micronuclei frequency in peripheral blood lymphocytes of thyroid cancer patients after radioiodine therapy and its relationship with metastasis. Mutat Res 675(12):35-40, 30

Kirsch-Volders M, Elhajouji A, Cundari E, Van Hummelen P (1997) The in vitro macronucleus test: a multi-endpoint assay to detect simultaneously mitotic delay, apoptosis, chromosomal breakage, chromosome loss and non disjunction. Mutat Res 392:19-30

Kocaman AY, Rencuzogullari E, Basrilla H, Topaktas M (2008) The genotoxic effect of potassium metabisulfite using chromosome aberration, sister chromatid exchange, micronucleus tests in human lymphocytes and chromosome aberration test in bone marrow cells of rats. Environ Mol Mutagen 49 (4):276-282

Lamberti L, Ponzetto PB, Ardito G (1983) Cell kinetics and sister chrom-atid exchange frequency in human lymphocytes. Mutat Res 120:193-199

Leach NT, Cook CJ (2004) Micronuclei with multiple copies of the X chromosome: do chromosomes replicate in micronuclei? Fundam Mol Mech Mutagen 554(1-2):89-94

Livingston GK, Foster AE, Elson H (1993) Effect on vivoexposure to iodine-131 on the frequency and persistence of micronuclei in human lymphocytes. J Toxicol Environ Health 40:367-375

Medalia J (2011) The Japanese nuclear incident: technical aspects. Congressional Research Service p1-13

Neri M, Ceppi M, Knudsen LE, Merlo DF, Barale R, Puntoni R et al (2005) Baseline micronuclei frequency in children: estimates from meta- and pooled analyses. Environ Health Perspect $113: 1226-1229$ 
Sbrana S, Franca V, Maria N, Aldamaria P, Roberto B (2006) Chromosomal fragile sites FRA3B and FRA16D show correlated expression and association with failure of apoptosis in lymphocytes from patients with thyroid cancer. Genes Chromosomes Cancer 45(5):429-436

Scarpato R, Tusa I, Antonelli A, Fallhai P, Sbrana I (2009) Spontaneous and bleomycin-induced chromosome damage in non cancer thyroid patients. Eur J Clin 39:1091-1097

Scarpato R, Verola C, Fabiani B, Bianchi V, Saggese G, Federico G (2011) Nuclear damage in peripheral lymphocytes of obese and overweight Italian children as evaluated by the $\gamma$-H2AX focus assay and micronucleus test. FASEB J 10-168427

Thierens H, Vral AM, Mohier R, Aousalan B, Ridder DL (2000) Cytogenetic monitoring hospital workers occupationally exposed ionizing radiation using the micronucleus centromere assay. $\mathrm{Mu}-$ tagenesis 15:245-249

Tronko M, Bogdanova T, Likhtarev I et al (2007) Thyroid gland and radiation: 20-years after the Chernobyl accident. In: Shibata Y, Namba H (eds) Radiation Risk Perspectives. Elsevier, Amsterdam, pp 46-53

Wilkens L, Benten D, Tchinda J, Brabant G, Potter E, Dralle H, von Wasielewski R (2000) Aberrations of chromosomes 5 and 8 as recurrent cytogenetic events in anaplastic carcinoma of the thyroid as detected by fluorescence in situ hybridisation and comparative genomic hybridisation. Virchows Arch 436:312-318

Yaqoub A, Ajeel N, Al-Wiswasy M (1998a) Incidence and pattern of malignant diseases (excluding leukemia) during 1990-1997. Proceeding of the conference on health and environmental consequences of DU used by U.S. and British forces in the $1991 \mathrm{Gulf}$ War Baghdad Iraq

Yaqoub AA, Al-Sadoon I, Hassan J (1998b) Incidence and pattern of malignant diseases among children in Basrah with specific reference to leukemia during the period of 1990-1998, Proceeding of the conference on health and environmental consequences of DU used by U.S. and British forces in the 1991 Gulf War Baghdad Iraq

Yaqoub A, Ajeel N, Al-Wiswasy M (1999) Depleted Uranium and health of people in Basrah: an epidemiological evidence; 1-The incidence and pattern of malignant diseases among children in Basrah with specific reference to leukemia during the period of 1990-1998. Med J Basrah Univ (MJBU) 17(1\&2):35-41

Yaqoub A, Al-Sadoon I, Hassan J (2002) The evidence of casual association between exposure to DU and malignancies among children in Basrah by applying epidemiological criteria of causality, Proceedings of the conference on the effects of the use of DU weaponry on human and environment in Iraq Baghdad Iraq 